\title{
Implementasi core value di sheraton bali kuta resort
}

\author{
I Nyoman Ari Wijaya ${ }^{1)}$, Agung Sri Sulistyawati ${ }^{2)}$, I Nyoman Jamin Ariana ${ }^{3)}$ \\ Program Studi Diploma IV Pariwis ata, Fakultas Pariwisata, Universitas Udayana \\ Jalan DR. R. Goris No. 7, Denpasar, Bali. 80114 \\ Email: ariwijaya8508@gmail.com
}

\begin{abstract}
Abstrak
Latar belakang penelitian ini bermula pada nilai dalam perusahaan Marriott yang dilaksanakan semua karyawan sebagai pedo man dalam bekerja yakni core value Marriott. Core value Marriott ialah nilaiinti perusahaan Marriott dalam menjalankan bisnisnya. Namun core value Marriott ini belumsepenuhnya dilaksanakan oleh karyawan, bahkan karyawan ada yang belumhafaldengan core value Marriott.Tujan penelitian yaitu untuk mengetahui implementasi dan pers epsi karyawan terhadap core value di Sheraton Bali Kuta Res ort. Jenis data penelit ian ini ialah data kualitat if dan kuant itatif. Sumber data ialah dataprimer dan sekunder. Teknik pengumpulan data yakni observasi, wawancara, kuesioner, dan dokumentasi. Teknikanalis is data yaitu deskript if kualitatif. Teknik penentuan sampel yakni propotional stratified random sampling disertai dengan simple random sampling. Hasil implementasi core value ialah implementasi put people first terkait program take care, job opportunity, s aranadan prasaranakesejahteraan, dan as uransibagiassociate. Implementasi persue excellence terkait programpelat ihanpengembangankari dan skill, cross training, dan associate award. Implementasi embrance change terkait pelat ihan dan sosialisasi perubahan jaman serta perkembangan teknologi. Implementasi act with integrity terkait see something, say something. Implementasi serve our world terkait kontribusi terhadap alamdan lingkungan mas yarakat sekitar. Persepsi karyawan terhadap core value di Sheraton Bali Kuta Resort ialah core value put people first yaitu 3,42 berkategori setuju, core value persue excellence yakni 4,2 berkategori setuju, core value embrance change ialah 4,29 berkategori sangat setuju, core value act with integrity ilah 4,14 berkategori setuju, dan core value serve our world yaitu 4,03 berkategori setuju. Perolehan persepsi associate atau karyawan terkait core value kes eluruhan yaitu 4,016 berkategori setuju. Saran padapenelitian ialah manajemen Sheraton Bali Kuta Resort senant iasa rutin sosialis asi terkait core value Marriott.

Kata kunci : Nilai, Implementasi, Persepsidan Core Value.
\end{abstract}

\begin{abstract}
The background of this research stems from the value in Marriott companies carried out by all employees as a guideline in working the Marriott core value. Marriott's core value is the core value of Marriott's company in running its business. But Marriott's core value has not been fully implemented by employees, even emplo yees have not memorized this core value. The purpose ofthis study was to determine the implementation and percept ion of employees towards core values at the Sheraton Bali KutaResort. The type of data in this study are qualitat ive and quantitative data. Data sources are primary and secondarydata. Data collect ion techniques are observation, interviews, questionnaires, and documentation. Thedataanalysis technique is descriptive qualitative. The sampling technique is proportional stratified randomsampling. Determination of samples by simple randomsampling. The result of the implementation of core is the implementation of put people first related to theprogramtake care, job opportunity, welfare facilities and infrastructure, and ins urance for as s ociates. Implement persue excellence related to careeranddevebpment training programs skill, cross training, and as s ociate awards. Implementation of embrance changerehtedto training and socialization of changing times and technological developments. Implement actions with integrity related to see something, say something. The implementation of serve our world is related to the contribution to nature and the surrounding communit y. Thepercept ion as sociate's or employee'softhecore value at the Sheraton Bali Kuta Resort is core value put people first is 3.42 categorized as agreed,corevahe persue excellence that is 4.2 categorized agree, core value embrance change is 4.29 categorzed strongly agree, core value act with integrity is 4.14 categorized agree, and core value serves our world which is 4.03 categorized agree. Obtaining anperception as sociate or employeerelated to the core value overallbf4,016 in the agreed category. Suggestions in this research are the management of the Sheraton Bali Kuta Res ort always regularly conducts socialization related to core values Marriott's.
\end{abstract}

Keywords : Values, Implementation, Perception, and Core Value. 


\section{PENDAHULUAN}

Perkembangan pariwisata di Indonesia sekarang sudah menyebar hampir disemua wilayah di Indonesia, termasuk pariwisata yang ada di Pulau Bali. Pada Tahun 2016 Bali memperoleh peringkat ke-5 dalam kategori Top 10 Island in the World (beritabali.com, 2016). Kemudian pada Tahun 2017 Bali dinobatkan sebagai destinasi w is ata terbaik dunia oleh Trip Advisor pada Traveller's Choice Aw ards 2017 (Tribun-Bali.com,2017).

Kabupaten Badung memiliki kawasan pariwisata, berbagai jenis usaha pariwisata, akses dan fasilitas umum yang mendukung kegiatan pariwisata yang lebih maju dibandingkan daerah lainnya di Bali. Sehingga banyak wisatawan nusantara maupun mancanegara yang berkunjung ke Kabupaten Badung. Adapun data terkait jumlah kunjungan wisatawan yang berkunjung ke Kabupaten Badung pada Tahun 2012 sampai Tahun 2016 yang dapat dilihat pada Tabel 1.

Tabel 1. Kunjungan Wisatawan ke Kabupaten Badung pada Tahun 2014 sampai 2018

\begin{tabular}{|c|c|c|c|c|}
\hline \multirow{2}{*}{ Tahun } & \multicolumn{2}{|c|}{$\begin{array}{l}\text { Jumlah Kunjungan Wisatawan } \\
\text { (Orang) }\end{array}$} & \multirow{2}{*}{$\begin{array}{c}\text { Total } \\
\text { Wisatawan } \\
\text { (Orang) }\end{array}$} & \multirow{2}{*}{$\begin{array}{l}\text { Pertumbuhan } \\
\qquad \%)\end{array}$} \\
\hline & Nusantara & Mancanegara & & \\
\hline 2014 & 498.933 & 1.053 .021 & 1.551 .954 & - \\
\hline 2015 & 761.451 & 1.470 .148 & 2.231 .599 & 43,7 \\
\hline 2016 & 1.597 .449 & 1.974 .418 & 3.571 .867 & 60 \\
\hline 2017 & 2.092 .271 & 1.751 .518 & 3.843 .789 & 7,61 \\
\hline 2018 & 2.658 .122 & 1.997 .413 & 4.655 .535 & 21,1 \\
\hline \multicolumn{4}{|c|}{ Rata-Rata Pertumbuhan } & 33,1 \\
\hline
\end{tabular}

Sumber: Badan Pusat Statistik Kabupaten Badung, 2019.

Berdasarkan pada Tabel 1, dapat dijelaskan bahwa adanya pertumbuhan dan peningkatan jumlah kunjungan wisataw an ke Kabupaten Badung dari Tahun 2014 sampai 2018. Pertumbuhan dan peningkatan jumlah kunjungan wisatawan tertinggi terjadi pada Tahun 2016. Adanya peningkatan tersebut membuat pemangku pariwisata yang ada di Kabupaten Badung terus mendirikan sarana akomodasi salah satunya hotel. Adapun data terkait jumlah hotel berbintang dan hotel melati yang ada di Kabupaten Badung berdasarkan kecamatannya pada Tahun 2018 dapat dilihat pada Tabel 2.

Tabel2. Jumlah Hotel Berbintang dan Hotel Melati di

Kabupaten Badung Berdasarkan Kecamatan PadaTahun 2018

\begin{tabular}{|l|c|c|c|c|}
\hline \multicolumn{1}{|c|}{ Kecamatan } & $\begin{array}{c}\text { Hotel } \\
\text { Berbintang }\end{array}$ & $\begin{array}{c}\text { Hotel } \\
\text { Melati }\end{array}$ & $\begin{array}{c}\text { Jumlah } \\
\text { Hotel }\end{array}$ & $\begin{array}{c}\text { Persentase } \\
(\%)\end{array}$ \\
\hline Kuta & 280 & 132 & 412 & 46,81 \\
\hline Kuta Selatan & 71 & 324 & 395 & 44,89 \\
\hline Kuta Utara & 5 & 61 & 66 & 7,50 \\
\hline Mengwi & - & 7 & 7 & 0,80 \\
\hline Abiansemal & - & - & - & 0 \\
\hline Petang & - & - & - & 0 \\
\hline Jumlah & 356 & 524 & 880 & 100 \\
\hline
\end{tabular}

Sumber: Badan Pus at Statistik Kabupaten Badung, 2019.

Berdasarkan pada Tabel 2, dapat diketahui bahwa jumlah hotel berbintang paling banyak dengan persentase tertinggi pada Tahun 2018 yaitu jatuh pada Kecamatan Kuta dengan jumlah 280 hotel berbintang dan 132 hotel melati. Marriot International adalah salah satu perusahaan yang bergerak dibidang industri hospitality terbesar di dunia berupa akomodasi yang memiliki lebih dari 6.500 properti di lebih dari 127 negara di seluruh dunia seperti di Amerika, China, Singapura, Inggris, termasuk juga Indonesia dengan memiliki 1,2 juta kamar (per September 2018) serta kamar tambahan 195.000 sedang dalam tahap pengembangan. Brand Marriott memiliki dua kelompok portofolio yaitu Classic dan 
Distinctive. Kelompok Classic adalah property yang memberikan pengalaman menginap kepada wisatawan dengan fasilitas mewah dan pelayanan yang ekslusif. Sedangkan, kelompok Distinctive adalah property yang lebih mengedepankan pelayanan dan fasilitas unik yang terkenal dengan gaya "santai" dan lifestyle. Kedua kelompok tersebut dibagi lagi ke dalam tiga kelas brand yaitu luxury, premium, dan select. Adapun terkait brand portofolio Marriott International dapat dilihat pada Tabel 3.

Tabel 3. Brand Portofolio Marriott International

\begin{tabular}{|c|c|c|}
\hline KelompokBrand & Kelas Brand & Nama Brand \\
\hline \multirow[t]{15}{*}{ Classic } & \multirow[t]{3}{*}{ Luxury } & JW Marriott Hotel \\
\hline & & ST. Regis Resort \\
\hline & & Ritz Carlton Res ort \\
\hline & \multirow[t]{5}{*}{ Premium } & Marriott Hotel \\
\hline & & Sheraton Hotel \\
\hline & & Marriott Vacation Club \\
\hline & & Delta Hotel by Marriott \\
\hline & & Marriott Executive Apartment(Long Stay Guest) \\
\hline & \multirow[t]{7}{*}{ Select } & Courtyard Hotel by Marriott \\
\hline & & Four Point by Sheraton \\
\hline & & Springhill Suites by Marriott \\
\hline & & Protea Hotelby Marriott \\
\hline & & Fairfield Inn \& Suite by Marriott \\
\hline & & Townplace Suiteby Marriott (Long Stay Guest) \\
\hline & & Marriott Residence Inn (Long Stay Guest) \\
\hline \multirow[t]{16}{*}{ Distinctive } & \multirow[t]{5}{*}{ Luxury } & Ritz Carlton Reserve \\
\hline & & W Hotel \\
\hline & & Edition Hotel \\
\hline & & The Luxury Collection \\
\hline & & BulgariHotels and Res ort \\
\hline & \multirow[t]{7}{*}{ Premium } & Le Meridien \\
\hline & & Westin Hotel \& Resort \\
\hline & & Autograph Collection Hotels \\
\hline & & Design Hotel \\
\hline & & Renais sance Hotel \\
\hline & & Tribute Portofolio Hotel \\
\hline & & Gaylord Hotel \\
\hline & \multirow[t]{4}{*}{ Select } & ACHotels by Marriott \\
\hline & & Aloft Hotels \\
\hline & & Moxy Hotels \\
\hline & & Element Hotels by Westin (Long Stay Guest) \\
\hline
\end{tabular}

Sumber: Human Resources Department Sheraton Bali Kuta Resort, 2019.

Marriott dinobatkan sebagai salah satu perusahaan terbaik dalam bidang industri hospitality berupa akomodasi berdasarkan pada Majalah Fortune. Kebetulan Marriott juga memperoleh peringkat 33 dari 100 perusahaan di seluruh dunia pada Majalah Fortune dalam kategori "100 Best Company to Work for 2017" dan 20 tahun berturut-turut berada di peringkat 100 besar dengan kategori "Great Place to Work Legend". Marriott memiliki nilai inti perusahaan yang dari awal sudah ada sejak bisnisnya dimulai yaitu core value Marriott. Adapun penjelasan core value Marriott tersebut 
Tabel4. Marriott's Core Value

\begin{tabular}{|c|c|}
\hline CORE VALUE & ARTI \\
\hline Put People First & \multirow{3}{*}{$\begin{array}{l}\text { Take care of associates and they will take care of the customers. } \\
\text { (Peduli dengan karyawan dan mereka akan peduli dengan para } \\
\text { pelanggan). }\end{array}$} \\
\hline (Mengutamakan & \\
\hline orang-orang) & \\
\hline Persue Excellence & \multirow{3}{*}{$\begin{array}{l}\text { Our dedication to customer shows in everything we do. } \\
\text { (Dedikasi kita kepada pelanggan terlihat di setiap y ang kita lakukan). }\end{array}$} \\
\hline (Mengejar & \\
\hline Keunggulan) & \\
\hline Embrace Change & \multirow{2}{*}{$\begin{array}{l}\text { Innovation has always been partofthe Marriott Story. } \\
\text { (Inovasi selalu menjadibagian dari cerita Marriott). }\end{array}$} \\
\hline (Menerima Perubahan) & \\
\hline Act With Interity & \multirow{3}{*}{$\begin{array}{l}\text { How we do business is as important as the business we do. } \\
\text { (Bagaimana kita melakukan bisnis adalah sama pentingnya dengan } \\
\text { bis nis yang kita lakukan). }\end{array}$} \\
\hline (Bertindak dengan & \\
\hline Integritas) & \\
\hline Serve Our World & $\begin{array}{l}\text { Our "Spirit To Serve" makes our company stronger. } \\
\text { (Semangat kita untuk melayani membuat perusahaan kita semakin kuat). }\end{array}$ \\
\hline
\end{tabular}

Sumber: Human Resources Department Sheraton Bali Kuta Resort, 2019.

Berdasarkan pada Tabel 4, dapat diketahui bahw a dalam core value Marriott yang pertama ialah Put People First, yakni seluruh hotel yang dikelola Marriott wajib mengutamakan kesejahteraan karyawan. Kedua ada Persue Excellence yaitu nilai motivasi bagi karyawan untuk bekerja dengan baik dan sempurna demi keunggulan dalam pelayanan jasa sebagai komitmen Marriott dalam menjalankan bisnis hospitality. Selanjutnya yang ketiga ada Embrace Change yaitu nilai yang menyalurkan inovasi dan kreasi karyawan dalam bekerja pada perubahan dan perkembangan jaman. Kemudian ada act with integrity yaitu nilai sikap yang senantiasa selalu taat pada aturan dan SOP dalam melakukan pekerjaan sehingga dapat menjaga kepercayaan atasan dan pelanggan tentunya. Core value Marriott yang terakhir adalah serve our world yaitu nilai yang mengarahkan karyawannya lebih pada kepedulian terhadap lingkungan dan masyarakat sekitar.

Sheraton Bali Kuta Resort merupakan salah satu hotel berbintang lima yang ada di Bali tepatnya di kawasan Pantai Kuta. Hotel ini juga merupakan salah satu properti yang telah diakuisisi dan dimiliki oleh Brand Marriott International. Adapula pesaing dari Sheraton Bali Kuta Resort dengan hotel lain yang satu manajemen dan juga berbintang lima yakni The Stones-Legian Bali - A Marriott Autograph Collection Hotels. Ada juga hotel berbintang lima lainnya yang menjadi pesaing Sheraton Bali Kuta Resort namun dengan manajemen yang berbeda. Adapun data terkait persaingan hotel berbintang lima yang ada di kawasan Pantai Kuta berdasarkan situs TripAdvisor dapat dilihat pada Tabel 5. 
Tabel 5. Peringkat 10 Bes ar Hotel Berbintang Lima

di Kawas an Pantai Kuta Berdasarkan ReviewPengunjung

\begin{tabular}{|l|l|l|}
\hline Peringkat & Nama Hotel & Jumlah Reviews \\
\hline 1 & Hardrock Hotel Bali & 5.110 \\
\hline 2 & Pullman Bali Legian & 3.890 \\
\hline 3 & Legian Beach Hotel & 2.272 \\
\hline 4 & Discovery Kartika Plaza & 2.160 \\
\hline 5 & The Stone Hotel & 1.785 \\
\hline 6 & Kuta Paradiso & 1.585 \\
\hline 7 & Mercure Kuta Beach Bali & 1.510 \\
\hline 8 & Rama Beach Resort and Villas & 1.480 \\
\hline 9 & Kuta Seaview Boutique & 1.429 \\
\hline 10 & Sheraton Bali Kuta Resort & 1.333 \\
\hline
\end{tabular}

Sumber:TripAdvisor, 2018.

Berdasarkan pada Tabel 5, dapat diketahui bahwa hasil review pada tabel merupakan pelayanan atau hospitality yang diberikan dari karyawan kepada tamu. Hotel berbintang lima di kawasan Pantai Kuta yang memiliki jumlah review paling tinggi adalah Hardrock Hotel Bali dengan 5,110 reviews. Kemudian diperingkat berikutnya Pullman Bali Legian, lalu Legian Beach Hotel di peringkat ketiga, hingga pada peringkat ke sepuluh besar jatuh pada Sheraton Bali Kuta Resort dengan 1,333 reviews. Sheraton Bali Kuta Resort kalah saing sebagai sesama Marriott dalam review dengan The Stone Hotel yang berada di peringkat kelima. Adapun terkait dengan jumlah karyawan yang bekerja di Sheraton Bali Kuta Resort dapat dilihat pada Tabel 6.

Tabel 6. Jumlah Karyawan di Sheraton Bali Kuta Res ort Tahun 2019

\begin{tabular}{|l|l|c|}
\hline No. & Departemen & Jumlah Karyawan (Orang) \\
\hline 1 & Execitive Office & 3 \\
\hline 2 & Engineering & 13 \\
\hline 3 & Human Resources & 4 \\
\hline 4 & Front Office & 32 \\
\hline 5 & Sales \& Marketing & 16 \\
\hline 6 & Housekeeping & 29 \\
\hline 7 & Finance & 12 \\
\hline 8 & IT & 1 \\
\hline 9 & F\&B General & 4 \\
\hline 10 & F\&B Service & 35 \\
\hline 11 & F\&B Kitchen & 40 \\
\hline 12 & Security & 4 \\
\hline 13 & Spa \& Recreation & 12 \\
\hline \multicolumn{2}{|c|}{ Total } & 205 \\
\hline
\end{tabular}

Sumber: Human Resources Department Sheraton Bali Kuta Res ort, 2019.

Berdasarkan pada Tabel 6, dapat diketahui bahw a jumlah karyaw an yang bekerja di Sheraton Bali Kuta Resort sebanyak 205 orang yang terbagi dalam 13 departemen. Adapun data terkait tingkat hunian kamar di Sheraton Bali Kuta Resort pada Tahun 2013 sampai 2017 dapat dilihat pada Tabel 7.

Tabel7. Tingkat Hunian Kamar Sheraton Bali Kuta Res ort Tahun 2014-2018

\begin{tabular}{|l|l|l|l|}
\hline Tahun & Tingkat Hunian Kamar $(\%)$ & Target & Pertumbuhan $(\%)$ \\
\hline 2014 & 78,10 & 79 & - \\
\hline 2015 & 79,06 & 80 & 1,23 \\
\hline 2016 & 83,22 & 80 & 5,26 \\
\hline 2017 & 71,51 & 81 & $-14,07$ \\
\hline 2018 & 76,74 & 81 & 7,31 \\
\hline
\end{tabular}

Sumber: Sales \& Marketing Sheraton Bali Kuta Resort, 2019. 
Berdasarkan pada Tabel 7, dapat diketahui bahwa tingkat hunian kamar di Sheraton Bali Kuta Resort selama lima tahun terakhir terus mengalami peningkatan. Peningkatan tertinggi yang mampu melebihi dari target yang ditentukan tejadi pada tahun 2016 yaitu sebesar 5,26 persen. Namun pada tahun 2017 mengalami penurunan secara drastis sebesar 14,07 persen. Penurunan ini diakibatkan oleh adanya travel warning bagi para wisatawan yang akan datang ke Bali ketika peristiwa bencana alam berupa erupsi Gunung Agung. Kemudian pada Tahun 2018 kembali mengalami peningkatan pertumbuhan tertinggi dalam lima tahun terakhir namun belum mencapai target yang ditetapkan.

Sudah menjadi kewajiban bagi karyaw an Sheraton Bali Kuta Resort untuk membangun visi dan misi perusahaan dalam meningkatkan kinerja dan kualiatas pelayanan terbaik. Sehingga perlu adanya kegiatan yang dilakukan untuk mewujudkan nilai-nilai yang tertuang dalam core value Marriott. Adapun core value Marriott yang belum sepenuhnya dilaksanakan antar karyawan. Misalnya kurangnya kepedulian sebagian besar karyaw an akan kegiatan take care yang salah satu kegiatannya yakni kegiatan jogging sore setiap hari kamis pukul 16.00 sampai 17.00, sehingga kegiatan ini hanya diikuti oleh beberapa karyaw an saja. Kemudian ada Job Opportunity low ongan bagi semua yang ingin menjadi bagian dari Marriott salah satunya juga bagi orang-orang yang berkebutuhan khusus (disabilitas). Namun terkait fakta di lapangan bahwa orang yang disabilitas kurang mendapatkan perhatian dari karyawan lain ketika bekerja dan bahkan jarang untuk diajak berkomunikasi untuk sekedar peduli akan keberadaan mereka (bagian terkait Put People First dalam core value Marriott).

Hotel Sheraton Bali Kuta Resort yang mejadi bagian dari manajemen Marriott dituntut agar bekerja secara professional serta mampu mengimplementasikan nilai-nilai inti Marriott. Ketika melakukan studi pendahuluan dan kebetulan juga sedang mengikuti training, peneliti mengamati bahwa masih saja ditemukan banyak karyawan yang kurang hafal bahkan tidak hafal sama sekali dengan core value Marriott. Padahal core value Marriott sudah terpampang pada setiap poster yang ada di koridor hotel. Bahkan pengetahuan tentang core value Marriott juga menjadi salah satu pembahasan ketika morning briefing. Apalagi ketika ada suspection auditor yang berkunjung dan menginap di Sheraton Bali Kuta Resort, seluruh karyawan mulai agak panik dan sibuk untuk menghafal core value Marriott maupun Brand Marriott lainnya. Hal ini sebagai pengetahuan umum mengenai Marriott yang sudah dibahas ketika training ataupun pada acara sosialisasi di Sheraton Bali Kuta Resort. Namun hal mendasar yang harus diketahui dan dijalankan oleh karyawan adalah mengenai core value Marriott ini, karena core value ini merupakan visi dan misi yang dipegang oleh Marriott dalam menjalankan bisnisnya di seluruh dunia. Sudah seharusnya karyaw an terbiasa dan paham terkait dengan core value Marriott yang sering dibahas. Namun tidak cukup hanya sekedar paham dan hafal dengan core value Marriott, tapi alangkah lebih bermanfaat dan bermakna apabila nilai-nilai dalam core value Marriott dapat diimplementasikan secara maksimal oleh seluruh karyawan Hotel Sheraton Bali Kuta Resort di setiap pekerjaannya.

Berdasarkan pada kasus di atas, pentingnya mengimplementasikan secara penuh nilai inti perusahaan yang dalam hal ini ialah cole value Marriott. Maka dari itu peneliti tertarik mengkaji untuk meneliti "Implementasi Core Value di Sheraton Bali Kuta Resort".

\section{METODE PENELITIAN}

Penelitian ini menggunakan teknik pengumpulan data dengan observasi, wawancara, dokumentasi, dan kuesioner. Teknik penentuan informan adalah purposive sampling. Sampel yang digunakan adalah 105 orang karyawan yang bekerja di Sheraton Bali Kuta Resort. Analisis data yang digunakan adalah deskriptif kualitatif dan kuantitatif yang ditunjang dengan skala likert. 


\section{HASIL DAN PEMBAHASAN}

Sheraton Bali Kuta Resort dibuka pada tanggal 1 Desember 2012, yang dibuka secara resmi oleh Presiden Starwood Hotels \& Resorts Asia Pacific, Miguel Ko dan Boyke Ghazali sebagai sebagai pemegang saham terbesar. Sebelum berdirinya Sheraton Bali Kuta Resort, hotel ini dikenal sebagai Sahid Hotel, yang kini telah berpindah tangan dan berdiri di bawah naungan manajemen Starw ood. Sheraton Bali Kuta Resort adalah salah satu hotel yang dikelola oleh Starwood Hotels \& Resorts Worldwide. Sheraton Bali Kuta Resort menandai Starwood Hotel kelima di Bali. Saat ini, Starw ood mengelola The St. Regis Bali Resort, W Retreat \& Spa Bali-Seminyak, The Laguna, A Luxury Collection Resort, dan The Westin Resort Nusa Dua, Bali. Pada tahun 2014, Starwood telah membangun tiga hotel baru di Bali, menandai total delapan hotel yang mewakili enam gaya hidup merek Starw ood Hotel.

Sheraton Bali Kuta Resort merupakan salah satu hotel starwood berbintang lima di kawasan pantai kuta dengan lokasi di Jalan Pantai Kuta, Kecamatan Kuta, Kabupaten Badung, Bali. Sheraton Bali Kuta Resort secara resmi dibuka pada pertengahan bulan Desember tahun 2012 oleh Bapak Soesilo Soedarman selaku Menteri Pariw is ata Post dan Telekomunikasi pada periode tersebut. Pemilik dari Sheraton Bali Kuta Resort berasal dari Jakarta yaitu perusahaan PT Indonesian Paradise Island Tbk, yang berkantor di Beachwalk Kuta dan manajemennya merupakan bagian dari Starw ood Hotels and Resorts. Dari awal operasi sampai saat ini, Sheraton Bali Kuta Resort dipimpin oleh Dario Orsini selaku General Manager.

\section{Implementasi Core Value di Sheraton Bali Kuta Resort}

Program Pengenalan Core Value

1) In The Beginning (ITB)

In The Beginning atau ITB merupakan salah satu program orientasi bagi karyawan. Adapun Marriott memiliki istilah dalam menyebut karyawannya yaitu associate. Associate tidak hanya untuk karyaw an tetap, namun juga untuk karyaw an kontrak, management trainee atau voyager, dan

trainee juga disebut sebagai associate. Program In The Beginning ini dilaksanakan oleh Training Manager serta dibantu oleh associate dari human resources yang ada di Sheraton Bali Kuta Resort. Program In The Beginning ini dialokasi waktu selama enam belas jam yang terbagi dalam dua sesi, yakni In The Beginning chapter one dan In The Beginning chapter two.

\section{2) Living Our Core Value (LOCV)}

Living Our Core Value merupakan program rutin yang dilaksanakan oleh pihak manajemen Marriott yang bertujuan agar associate atau karyaw an tetap ingat dan memahami core value yang ada. Program ini dilaksanakan secara rutin minimal sekali dalam setahun. Seluruh karyawan wajib

untuk ikut dalam program ini. Sama juga halnya, living our core value dibagi atas beberapa sesi dengan tujuan supaya tidak mengganggu kegiatan operasional hotel yang dimana karyaw an dapat bergiliran untuk mengikuti kegiatan ini. Pada tahun 2010 ada suatu program yang menjadi cikal bakal dari program living our core value yakni program well being. Program ini mulanya cuma terkaitdengan kesejahteraan jasmani seperti olah raga serta tips untuk menjaga kesehatan. Namun pada tahun 2012 mengalami perkembangan, sehingga dibentuklah program yang terkait dengan kesejahteraan karyawan yaitu program take care. Seperti misalnya terkait finansial karyawan, pengembangan karir yang berlandaskan nilai dari core value Marriott. 
Program Implementasi Core Value

1) Put people first

Put people first merupakan core value yang menempatkan karyaw an sebagai prioritas utama. Hal ini sebagai bentuk kepedulian perusahaan Marriott terkait dengan kesejahteraan karyawannya.

Berikut ini implementasi yang dilaksanakan dalam upaya untuk kesejahteraan karyawan yang bekerja di Sheraton Bali Kuta Resort.

\section{i. Take Care}

Namun sebelum adanya take care ini sudah ada yang namanya well being. Well being ialah program yang cuma memprioritaskan pada kesejahteraan kesehatan jasmani bagi karyawannya. Kemudian diganti dengan istilah take care. Take Care merupakan salah satu kegiatan yang dicetuskan oleh perusahaan Marriott yang lebih mengedepankan kepedulian akan kesejahteraan karyaw an. Maka yang menjadi prioritas tidak cuma kebutuhan jasmani dari karyaw annya, namun juga pada terpenuhinya kesejahteraan bagi karyawannya.

ii. Job Opportunity

Sheraton Bali Kuta Resort memberikan kesempatan kepada siapapun yang berminat untuk menjadi bagian dari properti Marriott. Maka dengan gencar-gencarnya, membuka low ongan bagi trainee, apperantice, dan voyager untuk bekerja di perusahaan Marriott. Untuk status trainee dan apperantice diberi pada siswa atau mahasiswa ataupun orang aw am yang memiliki latar belakang baik yang bereinginan memperoleh kesempatan kerja dan pengalaman dalam pengembangan karirnya di industri hospitaliti. Adapun Sheraton Bali Kuta Resort juga memberi kesempatan bagi orang yang berkebutuhan khusus ikut terlibat untuk bekerja di industri perhotelan. Hal ini dapat merubah pemikiran sebagian besar orang, bahwa tidak hanya yang sehat secara fisik dan mental dapat memperoleh pekerjaan. Tetapi juga berhak didapatkan oleh orang-orang yang patut kita pedulikan keberadaannya (disabilitas).

\section{iii. Sarana dan Prasarana Kesejahteraan Associate}

Sheraton Bali Kuta Resort di bawah naungan Marriott menyediakan sarana dan prasarana yang digunakan untuk menunjang kegiatan operasional hotel. Namun ada juga sarana maupun prasarana yang disediakan dalam mendukung kesejahteraan karyawan atau associate. Adapun sarana dan prasarana yang terdapat di Sheraton Bali Kuta Resort yang mungkin tidak ada di hotel lain yaitu GPS Lounge. GPS Lounge menyediakan fasilitas berupa komputer yang bisa diakses untuk sekedar internetan, menonton film atau movie, bermain musik, serta ruang kegiatan yang sering dipakai untuk kordinasi kegiatan HRD yang berhubungan dengan kesejahteraan karyaw an yang dipandu langsung oleh human resources. Kemudian Sheraton Bali Kuta Resort juga menyediakan ruangan kesehatan atau klinik yang diperuntukkan bagi associate untuk berobat yaitu in house clinic. Namun apabila wisataw an memerlukan pertolongan pertama untuk pengobatan medis, dokter yang ada di in house clinic akan melakukan pengobatan langsung ke kamar wisatawan. Selain itu ada pula sarana yang paling penting bagi karyawan atau associate yang ada di Sheraton Bali Kuta Resort yaitu Career Development Center (CDC). Career Development Center merupakan ruangan yang dipakai untuk kepentingan karyawan atau associate untuk program pengembangan karir dan skill dari karyawan itu sendiri. Career Development Center memiliki kelas atau program training rutin bagi karyawan untuk peningkatan dalam pengembangan karir dan skillnya. Adapun pengembangan karir dan skill karyawan tidak hanya diperoleh dari pelaksanaan kelas training langsung di dalam ruangan CDC. Tetapi ada juga memfasilitasi kelas training yang dapat diakses langsung secara online di internet oleh associate Marriott melalui website Marriott Global Source atau sering disebut dengan MGS. Marriott Global Source ialah website yang menyangkut segala informasi terkait kegiatan operational Marriott di seluruh dunia. MGS ini hanya bisa diakses oleh associate Marriott melalui ID associate yang telah diperoleh langsung ketika bergabung dalam perusahaan Marriott.

iv. Asuransi dan Jaminan Kesehatan 
Seluruh karyawan yang bekerja di Marriott diberikan jaminan kesehatan yang berupa asuransi

kesehatan. Sheraton Bali Kuta Resort memfasilitasi asuransi yang diwajibkan atas kebijakan dari pemerintah yaitu BPJS tenaga kerja serta BPJS kesehatan bagi karyawan. Sebagai bentuk ketaatan dari Sheraton Bali Kuta Resort terhadap aturan yang ditetapkan dan berlaku di Indonesia. Selain itu sebagai salah satu bentuk implementasi dari core value put people first.

\section{2) Persue Excellence}

Persue Excellence merupakan suatu nilai yang mengharuskan associate untuk meningkatkan performa atau kinerjanya secara maksimal supaya wisataw an yang menginap merasa puas atas pelayanan yang diberikan. Sehingga perlu adanya pelatihan bagi karyawan dalam menunjang peningkatan kompetensi yang dimiliki. Adapun pelaksanaan core value persue excellence dalam meningkatkan kompetensi karyaw an ialah sebagai berikut.

1) Training pengembangan karir dan skill

Pelaksanaan core value persue excellence lebih berfokus pada training pengembangan karir dan

skill bagi karyawan. Tujuan dari core value ini tentu lebih pada peningkatan kemampuan karyaw an berdasarkan target yang ditetapkan. Training hour sebagai durasi waktu training yang wajib diselesaikan setiap bulannya oleh semua karyawan yang bekerja di Sheraton Bali Kuta Resort.

\section{2) Associate Award}

Associate Award merupakan suatu bentuk penghargaan yang diberikan kepada karyawan berprestasi dengan kinerja yang baik. Pemberian ini dilaksanakan setiap tiga bulan. Ada dua buah kategori penghargaan pada associate award yakni associate of the quarter year dan manager of the quarter year. Bentuk penghargaan ini juga menjadi motivasi bagi karyawan supaya lebih giat dalam bekerja.

\section{3) Embrance change}

Embrance change merupakan core value Marriott untuk mengingatkan supaya manajemen serta karyaw an yang bekerja di Marriott khususnya Sheraton Bali Kuta Resort terbuka ataupun mampu berinovasi atas segala bentuk perubahan jaman. Pelaksanaan core value embrance change ini sebagian besar diimplementasikan dalam kegiatan training atau sosialisasi terkait teknologi modern dan tren global yang ada. Penyampaian informasi yang terkait dengan teknologi dalam penunjang kegiatan operasional hotel yaitu Marriott mobile application dan teknologi keyless. Marriott mobile application merupakan sebuah aplikasi yang khusus diberikan kepada member Marriott untuk mengakses check in hingga booking kamar hotel secara online. Sebelumnya perlu dijelaskan bahwa Sheraton Bali Kuta Resort memiliki member Marriott yang disebut dengan istilah Sheraton Preference Guest (SPG). Member Marriott dapat mengakses aplikasi ini melalui smartphone hingga dapat menentukan atau request terkait aminities yang diinginkan pada kamar yang akan di booking. Ada pula yang namanya teknologi keyless, dimana teknologi ini pada mulanya dipakai oleh member loyalty dari perusahaan Starwood. Namun sekarang tenologi ini sudah diterapkan oleh Marriott. Teknologi keyless merupakan tekonologi pengganti kunci manual pada hotel dengan menggunakan akses melalui smartphone sebagai kunci kamar.

\section{4) Act With Integrity}

Sheraton Bali Kuta Resort dibawah naungan Marriott senantiasa amat menjunjung nilai kejujuran, kepercayaan, integritas serta keamanan bersama. Maka oleh sebabnya, act with integrity sebagai core value yang diperlu diperhatikan oleh karyawan dalam bekerja. Pelaksanaan dari act with integrity ialah see something say something. See something say something adalah bentuk kalimat slogan bagi karyaw an atau associate apabila menemukan sesuatu yang mencurigakan atau sesuatu barang atau benda lain yang bukan pada tempatnya. Jika menemukan keadaan tersebut agar segera melaporkannya kepada security. Tujuannya tidak semata-mata untuk melaporkan bahaya 
seperti ancaman bom dan teroris, namun juga demi keselamatan kerja serta keamanan dan kenyamanan wisatawan.

\section{5) Serve Our World}

Serve our world merupakan suatu nilai dalam bentuk pemberian kontribusi kepada masyarakat

dan lingkungan sekitar. Sesuai dengan pernyatan dari pendiri Marriott, bahwa dalam menjalankan bisnisnya, memiliki prinsip bahwa suatu bisnis tidak semata-mata mencari untung. Namun juga harus bermanfaat bagi masyarakat dan lingkungan sekitar. Bentuk pelaksanaan dari core value serve our world Sheraton Bali Kuta Resort yaitu program spirit to serve. Program ini harus diikuti oleh associate yang menjadi perwakilan pada tiap-tiap departemen di Sheraton Bali Kuta Resort. Beberapa bentuk kegiatan spirit to serve yang dilaksanakan terbagi atas dua yakni kegiatan yang rutin diadakan setiap minggu dan rutin dalam setahun. Program kegiatan yang rutin dilaksanakan setiap minggu ialah beach cleaning.

\section{Karakteristik Responden Berdasarkan Jenis Kelamin, Usia, Pendidikan Terakhir, Masa Kerja, dan Jabatan}

Berdasarkan pada hasil penelitian di Sheraton Bali Kuta Resort, untuk mengetahui krakteristik responden dapat diperoleh dari identitas responden yang terdiri dari jenis kelamin, usia,

pendidikan terakhir, masa kerja, dan jabatan karyaw an.

\section{Jenis Kelamin Responden}

Menurut hasil dari kuesioner yang disebar sebanyak 105 responden di hotel Sheraton Bali Kuta Resort, diperoleh bahwa karakteristik responden dengan jenis kelamin laki-laki adalah 69 orang dengan persentase yakni 65,71 persen, sedangkan untuk jumlah responden dengan jenis kelamin perempuan adalah 36 orang dengan persentase yaitu 34,29 persen. Sehingga persentase karyawan atau associate dari Sheraton Bali Kuta Resort yang berjenis kelamin laki-laki lebih banyak dibandingkan dengan persentase karyaw an yang berjenis kelamin perempuan.

2 . Usia

Responden

Menurut hasil dari kuesioner yang disebar sebanyak 105 responden di hotel Sheraton Bali Kuta Resort, diperoleh bahwa karakteristik responden dengan usia kurang dari 21 tahun adalah 1 orang dengan persentase 0,00 persen, untuk jumlah responden dengan usia 21 sampai 30 tahun ialah 50 orang dengan persentase 47,62 persen, untuk jumlah responden dengan usia 31 sampai 40 tahun yakni 43 orang dengan persentase 41 persen, serta jumlah responden dengan usia 40 tahun keatas yaitu 11 orang dengan persentase 10,48 persen. Sehingga karyaw an atau associate dari Sheraton Bali Kuta Resort yang memiliki persentase tertinggi dan jumlah paling banyak jatuh pada usia 21 sampai 30 tahun yaitu 47,62 persen sejumlah 50 orang. Jadi, bisa dikatakan bahwa karyawan atau associate yang sebagian besar bekerja di Sheraton bali Kuta Resort sedang berada dalam usia yang produktif.

\section{Pendidikan Terakhir Responden}

Menurut hasil dari kuesioner yang disebar sebanyak 105 responden di hotel Sheraton Bali Kuta Resort, diperoleh bahwa karakteristik responden dengan pendidikan terakhir paling tinggi berada pada jenjang SMA/SMK dengan persentase 40 persen sejumlah 42 orang, kemudian urutan berikutnya pada jenjang DIV/S1 dan DI/DII/DIII dengan jumlah persentase yang sama yaitu 29,52 persen dan jumlah yang sama yakni sebanyak 31 orang. Selanjutnya pada jenjang S2 dengan persentase 0,95 persen sejumlah satu orang saja. Terakhir untuk responden pada jenjang SD dan SMP tidak ada sama sekali. 


\section{Masa Kerja Responden}

Menurut hasil dari kuesioner yang disebar sebanyak 105 responden di hotel Sheraton Bali Kuta Resort, diperoleh bahwa karakteristik responden dengan masa kerja tertinggi yaitu 5 tahun adalah 56 orang dengan persentase 53,33 persen. Setelah itu, pada masa kerja 2 sampai 3 tahun sejumlah 32 orang dengan persentase sebesar 30,48 persen. Lalu yang terakhir dengan masa kerja 1 sampai 2 tahun sejumlah 17 orang dengan persentase sebesar 16,19 persen.

5. Jabatan Responden

Menurut hasil dari kuesioner yang disebar sebanyak 105 responden di hotel Sheraton Bali Kuta Resort, diperoleh bahwa karakteristik responden dengan peraihan persentase sebesar 7,62 persen. Kedua, jumlah responden dengan jabatan sebagai Manager yaitu 4 orang dengan persentase sebesar 3,81 persen. Ketiga, jumlah responden dengan jabatan sebagai Supervisor yakni sejumlah 13 orang dengan persentase sebesar 12,38 persen. Kemudian yang terakhir, pada jumlah responden dengan jabatan sebagai Staff yaitu 80 orang dengan persentase sebesar 76, 19 persen.

\section{Persepsi Karyawan terhadap Implementasi Core Value di Sheraton Bali Kuta Resort}

Berdasarkan pada kuesioner yang sudah tersebarkan ke 105 responden mengenai core value di Sheraton Bali Kuta Resort memperoleh hasil yang dapat dilihat pada Tabel 8.

Tabel 8. Persepsi Karyawan terhadap Core Value

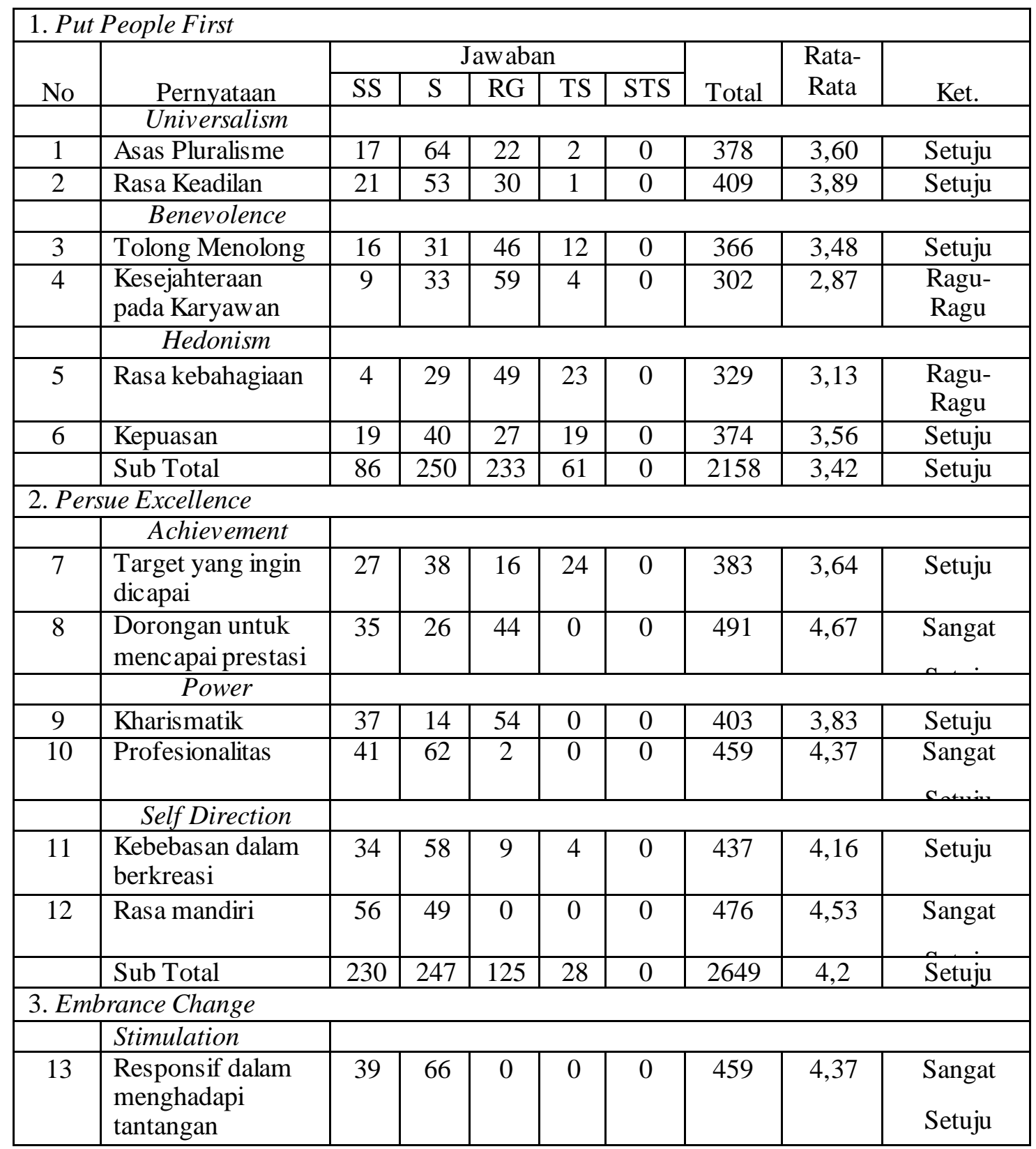




\begin{tabular}{|c|c|c|c|c|c|c|c|c|c|}
\hline 14 & $\begin{array}{l}\text { Dorongan } \\
\text { mengambil resiko }\end{array}$ & 30 & 68 & 7 & 0 & 0 & 443 & 4,21 & Sangat \\
\hline & Sub Total & 69 & 134 & 7 & 0 & 0 & 902 & 4,29 & Sangat \\
\hline \multicolumn{10}{|c|}{ 4. Act With Integrity } \\
\hline & Security & & & & & & & & \\
\hline 15 & $\begin{array}{l}\text { Partisipasi dalam } \\
\text { keamanan }\end{array}$ & 19 & 64 & 22 & 0 & 0 & 417 & 3,97 & Setuju \\
\hline \multirow[t]{2}{*}{16} & $\begin{array}{l}\text { Pemahaman terkait } \\
\text { keamanan }\end{array}$ & 16 & 68 & 21 & 0 & 0 & 415 & 3,95 & Setuju \\
\hline & Conformity & & & & & & & & \\
\hline 17 & Ketaatan & 42 & 63 & 0 & 0 & 0 & 462 & 4,4 & Sangat \\
\hline \multirow[t]{2}{*}{18} & Tanggung jawab & 27 & 78 & 0 & 0 & 0 & 447 & 4,25 & Sangat \\
\hline & Sub Total & 104 & 273 & 43 & 0 & 0 & 1741 & 4,14 & Setuju \\
\hline \multicolumn{10}{|c|}{ 5. Serve Our World } \\
\hline & Tradition & & & & & & & & \\
\hline 19 & Ras a menghormati & 29 & 76 & 0 & 0 & 0 & 449 & 4,27 & Sangat \\
\hline \multirow[t]{2}{*}{20} & Komitmen tinggi & 11 & 63 & 31 & 0 & 0 & 400 & 3,8 & Setuju \\
\hline & Sub Total & 40 & 139 & 31 & 0 & 0 & 849 & 4,03 & Setuju \\
\hline
\end{tabular}

Sumber: Hasil Pengolahan Data, 2019

\section{Persepsi Karyawan terhadap Core Value Put People First}

Berdasarkan pada Tabel 8, diperoleh hasil dari perhitungan skala likert dari 105 responden yaitu persepsi karyaw an terhadap core value Put People First di Sheraton Bali Kuta Resort dengan kategori setuju dan jumlah sub total yakni 3,42. Nilai tertinggi diperoleh pada pernyataan terkait rasa keadilan yakni 3,89. Membuktikan bahwa karyawan merasa implementasi core value put people first telah dilaksanakan namun belum sepenuhnya dapat berjalan dengan baik. Salah satunya dapat dilihat pada pernyataan terkait rasa kebahagiaan yang cenderung memperoleh respon tidak setuju tertinggi sejumlah 23.

Berdasarkan penelitian lebih lanjut dengan mengajukan pertanyaan kembali terkait persepsi

karyaw an yang memberikan penilaian dari kategori ragu sampai tidak setuju dapat diperoleh hasil bahwa sebagian besar dari 13 karyawan yang diajukan pertanyaan menyatakan masih belum merasa bahagia ketika bekerja. Sebagian besar berpendapat dan menilai karena beban kerja yang tidak sesuia dengan waktu yang dibutuhkan bekerja selama delapan jam dalam sehari membuat karyawan merasa tidak nyaman, selain itu kepedulian dari karyawan terhadap penyandang disabilitas masih kurang dan belum saling memiliki rasa kebersamaan dalam satu tim di jajaran karyaw an Sheraton Bali Kuta Resort.

Berdasarkan Schwartz (2012) value universalism terkait keadilan memperoleh kategori setuju serta pluralisme memperoleh kategori setuju. Value benevolence terkait tolong menolong memperoleh kategori setuju serta kesejahteraan karyawan cenderung hanya memperoleh kategori

ragu-ragu. Hedonism terkait kebahagiaan karyawan memperoleh kategori ragu-ragu juga sertakepuasan karyawan memperoleh kategori setuju. Perlu adanya evaluasi lebih lanjut terkait

pernyataan yang memperoleh kategori sedang. 


\section{Persepsi Karyawan terhadap Core Value Persue Excellence}

Selanjutnya hasil dari perhitungan skala likert dari 105 responden yaitu persepsi karyawan terhadap core value Persue Excellence di Sheraton Bali Kuta Resort dengan kategori setuju dan jumlah sub total yakni 4,2. Nilai tertinggi diperoleh pada pernyataan terkait dorongan untuk mencapai prestasi yakni 4,67. Tetapi ada juga perbedaan persepsi dapat dilihat pada pernyataan terkait target yang dicapai cenderung memperoleh respon tidak setuju tertinggi sejumlah 24 .

Berdasarkan penelitian lebih lanjut dengan mengajukan pertanyaan kembali terkait persepsi karyaw an yang memberikan penilaian dari kategori ragu sampai tidak setuju dapat diperoleh hasil bahwa sebagian besar dari 13 karyawan yang diajukan pertanyaan bahwa karyawan merasa implementasi core value persue excellence telah dilaksanakan dan dapat berjalan dengan baik. Tetapi ada juga perbedaan persepsi dapat dilihat pada pernyataan terkait target yang dicapai cenderung memperoleh respon tidak setuju tertinggi sejumlah 24. Adanya tuntutan terhadap target yang harus dicapai dengan mempertimbangkan pendapatan hotel dan tingkat huniar kamar yang membuat karyaw an memiliki beban dan tanggung jaw ab. Hal ini dikarenakan target dan tuntutan yang tinggi yang melebihi job desk yang diluar dari SOP yang berlaku. Sering dialami oleh karyawan selama melaksanakan pekerjaan yang relatif memiliki porsi kerja yang semestinya dikerjakan dua orang, namun dibebankan pada satu orang. Sehingga kinerja yang diberikan tidak maksimal dalam mencapai target bahkan melampaui target masih menjadi tanggung jaw ab. Karena sesuai dengan core value yang dianut yaitu persue excellence terkait target yang tercapai. Maka dapat dikatakan bahwa karyaw an ada yang masih belum merasa mencapai target ketika bekerja. Kemungkinan besar karena tuntutan kerja yang tinggi dari atasan, target yang tinggi, banyaknya evaluasi atau audit dari Marriott dalam waktu jangka pendek yakni sebulan sekali.

Berdasarkan Schwartz (2012) value achievement terkait target yang ingin dic apai memperoleh kategori setuju serta dorongan untuk mencapai target memperoleh kategori sangat setuju. Value power terkait kharismatik memperoleh kategori setuju serta profesionalitas karyaw an memperoleh kategori sangat setuju. Self direction terkait kebebasan dalam berkreasi memperoleh kategorisetuju serta terkait rasa mandiri karyawan memperoleh kategori sangat setuju. Perlu evaluasi terkait pernyataa kategori terendah dalam persue excellence yaitu target yang ingin dicapai mendapat kategori baik.

\section{Persepsi Karyawan terhadap Core Value Embrance Change}

Berikutnya hasil dari perhitungan skala likert dari 105 responden yaitu persepsi karyawan terhadap core value Embrance Change di Sheraton Bali Kuta Resort dengan kategori sangat setuju dan jumlah sub total yakni 4,29. Nilai tertinggi diperoleh pada pernyataan terkait responsif dalam menghadapai tantangan yakni 4,37. Membuktikan bahwa karyawan merasa implementasi core value embrance change telah dilaksanakan dan dapat berjalan dengan baik. Tetapi ada juga perbedaan persepsi dapat dilihat pada pernyataan terkait dorongan mengambil resiko cenderung memperoleh respon ragu - ragu tertinggi sejumlah 7.

Berdasarkan penelitian lebih lanjut dengan mengajukan pertanyaan kembali terkait persepsi karyaw an yang memberikan penilaian dari kategori ragu sampai tidak setuju dapat diperoleh hasil bahwa sebagian besar dari 13 karyaw an yang diajukan pertanyaan bahwa karyaw an ada yang masih merasa belum siap mengambil segala resiko ketika bekerja. Sebagian besar karena perubahanperubahan teknologi pada sistem yang digunakan oleh Marriott dalam menjalankan bisnisnya, adanya update system yang rutin dilakukan dalam jangka waktu 3 bulan sekali untuk perbaikan dan pembaharuan informasi dan data perusahaan serta banyaknya agenda kegiatan diluar jam kerja yang menjadi program kerja dari Marriott melalui delegasi dari human resources, pelaksanaan training associate secara rutin setiap dua minggu sekali. 
Berdasarkan Schwartz (2012) value stimulation terkait responsif dalam menghadapi tantangan memperoleh kategori sangat setuju serta dorongan mengambil resiko memperoleh kategori sangat setuju. Perlu adanya evaluasi lebih lanjut terkait pernyataan yang memperoleh kategori terendah dalam embrance change yaitu dorongan mengambil resiko yang mendapat respon ragu-ragu sejumlah 7 .

\section{Persepsi Karyawan terhadap Core Value Act With Integrity}

Kemudian hasil dari perhitungan skala likert dari 105 responden yaitu persepsi karyawan terhadap core value Act With Integrity di Sheraton Bali Kuta Resort dengan kategori setuju dan jumlah sub total yakni 4,14. Nilai tertinggi diperoleh pada pernyataan terkait ketaatan atau kepatuhan yakni 4,4. Membuktikan bahwa karyawan merasa implementasi core value act with integrity telah dilaksanakan dan namun perlunya adanya tindak lanjut terkait keamanan agar dapat berjalan dengan baik. Dibuktikan dengan adanya perbedaan persepsi dapat dilihat pada pernyataan terkait partisipasi dalam hal keamanan cenderung memperoleh respon tidak setuju tertinggi sejumlah 22. Kemudian disusul respon ragu-ragu sejumlah 21 pada pernyataan terkait pemahaman akan keamanan.

Berdasarkan penelitian lebih lanjut dengan mengajukan pertanyaan kembali terkait persepsi karyawan yang memberikan penilaian dari kategori ragu sampai tidak setuju dapat diperoleh hasil bahwa sebagian besar dari 13 karyaw an yang diajukan pertanyaan bahwa karyaw an ada yang masih belum merasa berpartisipasi secara penuh akan identifikasi keamanan dari program implementasi Marriott. Baik karena kesibukan ketika bekerja sehingga kurang perhatian pada aspek keamanan di tempat bekerja dan sudah merasa keamanan memang sudah menjadi tanggung jaw ab dari security secara penuh.

Berdasarkan Schwartz (2012) value security terkait partisipasi dalam keamanan memperoleh kategori setuju serta pemahaman terkait keamanan memperoleh kategori setuju. Value conformity terkait ketaatan atau kepatuhan memperoleh kategori sangat setuju serta pernyataan terkait tanggung jawab memperoleh kategori sangat setuju. Perlu adanya evaluasi lebih lanjut terkait pernyataan yang memperoleh respon ragu-ragu tertinggi dalam act with integrity yaitu partisipasi dalam keamanan dan pemahaman terkait keamanan.

\section{Persepsi Karyawan terhadap Core Value Serve Our World}

Terakhir hasil dari perhitungan skala likert dari 105 responden yaitu persepsi karyaw an terhadap core value Serve Our World di Sheraton Bali Kuta Resort dengan kategori setuju dan jumlah sub total yakni 4,03. Nilai tertinggi diperoleh pada pernyataan terkait rasa menghormati yakni 4,27. Membuktikan bahwa karyawan merasa implementasi core value serve our world telah dilaksanakan dan dapat berjalan dengan baik. Tetapi ada juga perbedaan persepsi dapat dilihat pada pernyataan terkait komitmen tinggi cenderung memperoleh respon ragu - ragu tertinggi sejumlah 31.

Berdasarkan penelitian lebih lanjut dengan mengajukan pertanyaan kembali terkait persepsi karyaw an yang memberikan penilaian dari kategori ragu sampai tidak setuju dapat diperoleh hasil bahwa sebagian besar dari 13 karyaw an yang diajukan pertanyaan bahwa karyaw an ada yang masih belum merasa berkomitmen akan kontribusinya pada lingkungan sekitar. Karena lebih berfokus pada kepentingan pribadi dalam hal pekerjaan sehingga tidak begitu peduli pada kondisi lingkungan sekitar. Namun pihak manajemen yang terlibat dalam Corporate Social Responsibility (CSR) terutama pihak human resources sudah ikut berpartisipasi dalam agenda kegiatan sosial dan adat masyarakat sekitar. Seperti pelaksanaan kegiatan gotong-royong di area Pantai Kuta dan lingkungan Desa Adat Legian.

Berdasarkan Schwartz (2012) value tradition terkait rasa menghormati memperoleh kategori sangat setuju serta komitmen tinggi memperoleh kategori setuju. Perlu adanya evaluasi lebih lanjut terkait pernyataan yang memperoleh kategori terendah dalam serve our world yaitu komitmen 
tinggi yang mendapat respon ragu-ragu tertinggi sejumlah 31.

\section{KESIMPULAN}

Berdasarkan pembahasan serta hasil analisis data sebelumnya, diperoleh simpulan yaitu implementasi core value di Sheraton Bali Kuta Resort ialah implementasi put people first terkait program take care, job opportunity, sarana dan prasarana kesejahteraan, dan asuransi bagi associate. Implementasi persue excellence terkait program pelatihan pengembangan karir dan skill, cross training, dan associate award. Implementasi embrance change terkait pelatihan dan sosialisasi perubahan jaman serta perkembangan teknologi. Implementasi act with integrity terkait see something, say something. Implementasi serve our world terkait kontribusi terhadap alam dan lingkungan masyarakat sekitar. Persepsi associate atau karyaw an terhadap core value di Sheraton Bali Kuta Resort ialah core value put people first yaitu 3,42 berkategori setuju, core value persue excellence yakni 4,2 berkategori setuju, core value embrance change ialah 4,29 berkategori sangat setuju, core value act with integrity ialah 4,14 berkategori setuju, dan corevalue serve our world yaitu 4,03 berkategori setuju. Perolehan persepsi associate atau karyaw an terkait core value keseluruhan yaitu 4,016 berkategori setuju.

\section{Ucapan terima kasih}

Kami menyampaikan ucapan terima kasih kepada Dekan Fakultas Pariwisata Universitas Udayana yang telah memberikan dukungan sehingga kegiatan Laporan Akhir ini bisa berjalan. Terima kasih juga kami sampaikan kepada Ketua Program Studi Diploma IV Pariw isata Fakultas Pariw isata atas fasilitas dan dukungan moral yang telah diberikan. Terima kasih juga saya sampaikan kepada kedua pembimbing saya yang telah membimbing dan mengarahkan penulis dalam menyelesaikan jurnal. Terima kasih juga kepada owner, general manager dan staff Sheraton Bali Kuta Resort yang telah meluangkan waktunya untuk memberikan informasi dan masukan serta data yang diperlukan dalam penelitian ini, serta semua pihak yang tidak dapat kami sebutkan satu persatu yang telah banyak membantu hingga terselesaikannya penelitian ini.

\section{DAFTAR PUSTAKA}

Arikunto. 2006. Prosedur Penelitian Suatu Pendekatan Praktek. Jakarta : PT. Rineka Cipta. Bagyono. 2012. Pariwisata dan Perhotelan. Bandung: Alfabeta.

Ivanis, Marija. 2016. Values And Ethical Behavior Of Hotel Managers Based On The SchwartzTheory Of Personal Values. Kroasia: Universitas Rijeka. Journal of Business Paradigms, Vol. 1 (1), 1-17.

Kamilie, Ivana dan Grace Kilis. 2014. "Pengaruh Dimensi Keberfungsian Keluarga terhadap Tipe Nilai Schwartz pada Mahasiswa Universitas Indonesia Tahun Pertama" (Sebuah Laporan Akhir). Depok: Universitas Indonesia.

Mees, Ulrich dan Annette Schitt. 2008. Goals of Action and Emotional Reasons for Action. A Modern Version of the Theory of Ultimate Psychological Hedonism. Journal for the Theory of Social Bahavior, vol 38, no. 2, hlm.158-178. Dengan situs: http://dx.doi.org/10.1111/j.1468-5914.2008.00364.x (diakses pada 21 Oktober 2018).

Robotham, David. 1995. Self-directed learning. Journal of European Industrial Training, vol.19, no.7, hlm.3-7. Dengan situs: http://dx.doi.org/10.1108/03090599510092918 (diakses pada 21 Oktober 2018).

Rohmad, Supriyanto. 2015. Pengantar Statistika: Panduan Praktis Bagi Pelajar dan Mahasiswa. Yogyakarta: Kalimedia.

Savarino, Dendy. 2008. Manajemen sekuriti fisik di BSP (Bekapal Senipah, Peciko) terminal Total E\& P Indonesie senipah Kalimantan timur. Depok: Universitas Indonesia. 
Schw artz, Shalom H. 2012. An Overview of the Schwartsz Theory of Basic Values, Online Reading in Psychology and Culture, vol.2, no. 1. Dengan situs: https://scholarw orks.gvsu.edu/orpc/vol2/iss 1/11/ (diakses pada 20 Oktober 2018).

Setiawan, Guntur. 2004. Implementasi dalam Birokrasi Pembangunan. Bandung: Remaja Rosdakarya Offset.

Sugiyono. 2013. Metode Penelitian Kuantitatif, Kualitatif dan R\&D. Bandung: PT Alfabet. Sugiyono. 2016. Metode Penelitian Kuantitatif, Kualitatif dan R\&D. Bandung: PT Alfabet. Sulastiyono, Agus. 2011. Manajemen Penyelenggaraan Hotel: Manajemen Hotel. Bandung: Alfabeta.

Tandio, Tan Jimmy. 2013. "Analisis Implementasi Transfering Value Antar Generasi pada Sebuah Family Business di Surabaya" (Sebuah Laporan Akhir). Surabaya: Universitas Kristen Petra. Tong, Yanqi. 2011. Morality, Benevolence, and Responsibility: Regime Legitimacy in China from Past to the Present. Journal of Chinese Political Science/Association of Chinese Political Studies, vol. 16, hlm.141-159. Dengan situs: https://link.springer.com/article/10.1007/s11366-011-9141-7 (diakses pada 21 Oktober 2018).

Usman, Nurdin. 2002. Konteks Implementasi Berbasis Kurikulum. Jakarta: PT. Raja Grafindo Persada.

Utama, I Gusti Bagus Rai dan Ni Made Eka Mahadewi. 2012. Metodologi Peneelitian Pariwisata \& Perhotelan. Yogyakarta: CV Andi Offset.

Utama, I Gusti Bagus Rai dan Ni Made Eka Mahadewi. 2016. Metodologi Peneelitian Pariwisata \& Perhotelan. Yogyakarta: CV Andi Offset.

Wallimann, Isidor.1977. On Max Weber's Definition of Power. Journal of Sociology, vol.13, no. 3, hlm.231-235. situs: http://journals.sagepub.com/doi/abs/10.1177/144078337701300308 （diakses pada 21 Oktober 2018).

https://mgs.marriott.com/. Diakses pada tanggal 25 Juli 2019.

http://mobileapp.marriott.com/. Diakses pada tanggal $25 \mathrm{Juli}$ 2019.

Sumber Lain:

beritabali.com,

2016. Tribun-

Bali.com,2017.

TripAdvisor, 2018.

Dinas Pariwisata Daerah Kabupaten Badung Tahun 2019. 